\title{
Preparation of lead-zirconiate-titanate using lead acetate by a sol-gel process 酢酸鉛を用いたゾルーゲル法によるチタン酸ジルコン酸鉛の作製
}

\author{
Yoichi ISHIMOTO, Nozomi IMAHORI and Jun-ichi MATSUSHITA \\ Department of Applied Chemistry, School of Engineering, Tokai University \\ 1117 Kitakaname, Hiratuka, Kanagawa 259-1292, Japan \\ TEL: 81-463-58-1211(ext.4186) FAX: 81-463-50-2012 \\ ( Received 14, November 1998 Accepted 12, June 1999 ) \\ Lead-zirconate-titanate (PZT) was prepared by a sol-gel process. As one process, lead acetate, zirconium tetra- $n$ - \\ butoxide, and titanium tetra-iso-propoxide were used as raw materials. 2-methoxyethanol and diethanolamine \\ were used as solvents. As another process, lead acetate, zirconyl nitrate, and titanium tetra- $n$-butoxide were \\ used as raw materials. Distilled water, acetic acid, and tri-ethylene glycol were used as solvents. PZT were \\ synthesized twelve ways on the basics to the two processes. Synthesized PZT by each had been dried for $24 \mathrm{~h}$ at \\ $338 \mathrm{~K}$. Dried samples had been sintered for $1 \mathrm{~h}$ at $773 \mathrm{~K}, 873 \mathrm{~K}$, and $1023 \mathrm{~K}$ in air. The sintered samples were \\ evaluated by X-ray analysis.
}

Keywords: PZT, sol-gel process, lead acetate

\section{INTRODUCTION}

チタン酸ジルコン酸鉛(PZT)は、圧電材料としての機 能を利用してセンサー、アクチュエーターなどに実用化 されている。

現在、主な製造方法である酸化物混合法においては、 大量生産性に富み、低価格化が実現されている。しかし、 固相反応であるため $1500 \mathrm{~K}$ 以上の高温での焼成が必要 であり、内部空孔が多く存在するなど均一性に欠けるた め高特性化がはかれないという欠点を有する。 高純度化、低温合成、形状付与性などの特徵を有する複 合酸化物の合成方法の一つであるゾルーゲル法を用いた PZT 作製の検討が盛んに行われいる。

そこで、本研究では、(1) 窒素雾囲気中において出発 原料に、金属アルコキシド、有機溶媒を用いる方法。 (2)大気中において、出発原料に水溶性の金属化合物お よび溶媒として水、酶酸を用いる方法をもとに計 12 パ ターンの PZT 溶液を調製し、PZT 粉末の合成を試みた。

\section{EXPERIMENTAL}

(1) はじめに、金属アルコキシドおよび有機溶媒を 用いる実験では、溶媒に2ーメトキシエタノールを用
い、窒素雰囲中で所定量の酢酸鉛無水物、ジルコニウ ムテトラーnーブトキシド、チタニウムテトライソプ ロポキシドおよび安定剤であるジエタノールアミンを 混合し、挸汼を行った。酢酸鉛が溶解後、ホットスタ 一ラ上において、423Kで 6 時間摫拌、還流を行った 後、蒸留を行った。最後に添加物として、2ーメトキ シエタノール水溶液を混合し、濃度を調整した後、大

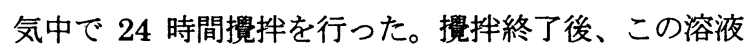
を乾燥器内で $343 \mathrm{~K} 、 24$ 時間乾燥し、得られた固体を 773K、873K、1023K でそれぞれ 1 時間焼成した。 Figure1 にPZT 粉末の作製過程を示す。

(2)つぎに、水溶性金属化合物を用いる実験では、30\% 酢酸水溶液に所定量の酢酸鉛無水和物、硝酸ジルコニル、 チタニウムテトラーnーブトキシドを $373 \mathrm{~K}$ に保ったホ ットスターラー上で溶かし、安定剤であるトリエチレン グリコールを混合し、摫汼、還流を行い、蒸留によって 濃度調整し、乾燥、焼成を行った。

さらに、上記の出発原料(溶媒、鉛源、ジルコニア源、 チタン源、安定剤)をそれぞれ組み替え、PZT 溶液を作 製し、乾燥、焼成を行った。 


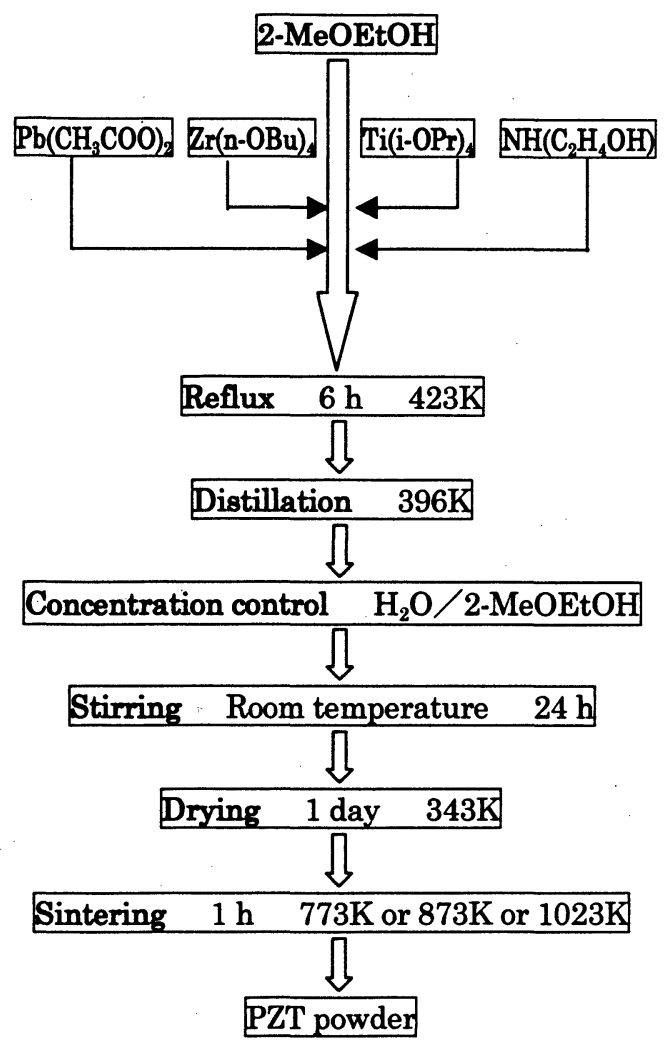

FIG.1. Schematic diagram of synthesizes process.

\section{RESULTS AND CONCLUSION}

PZT 溶液調製実験の結果を Table 1 に示す。なお、図 中の×印は、溶液調製実験の過程において沈殿物を生成 したものである。

TABLE 1. A combination of raw materials

\begin{tabular}{|c|c|c|c|c|c|c|c|c|c|c|c|c|c|}
\hline & No. & 1 & 2 & 3 & 4 & 5 & 6 & 7 & 8 & & 10 & 11] & \\
\hline \multirow{2}{*}{ Solvents } & 2-methoxyethanol & - & & & - & & & 0 & - & & - & & - \\
\hline & Acetic acid & & $\bullet$ & - & & 0 & c & & & 0 & & e & \\
\hline $\mathrm{Pb}$ & Lead acetate & - & - & 0 & 이 & 0 & - & 0 & 이 & 0 & - & - & - \\
\hline \multirow[t]{2}{*}{$\mathrm{Zr}$} & $\begin{array}{l}\text { Zirconium tetra } \\
\text {-n-butoxide }\end{array}$ & 0 & & 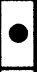 & & & & - & 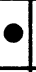 & 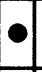 & • & & - \\
\hline & Zirconyl nitrate & & 이 & & - & 0 & 0 & & & & & - & \\
\hline \multirow{2}{*}{$\mathrm{Ti}$} & $\begin{array}{l}\text { Titanium tetraiso } \\
\text { propoxide }\end{array}$ & - & & & & & - & & - & & & 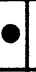 & - \\
\hline & $\begin{array}{l}\text { Titanium tetra } \\
\text {-n-butoxide }\end{array}$ & & & & & 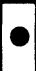 & & - & & c & • & & \\
\hline \multirow{3}{*}{ Stabilizer } & Diethanolamide & & & & & & & & & - & 으 & 으 & 으 \\
\hline & Triethyleneglycol & e & & & 0 & 0 & 이 & e & 으 & & & & \\
\hline & Results & 익 & & & & & & & & & & & 이 \\
\hline
\end{tabular}

$O$ : Success 、 $x$ : Failure

つぎに、Table 1 中の No.2 および No.12 の方法によ って調製した PZT 粉末試料の X 線回折分析法による構 造解析結果を Fig. 2 および Fig. 3 に示す。

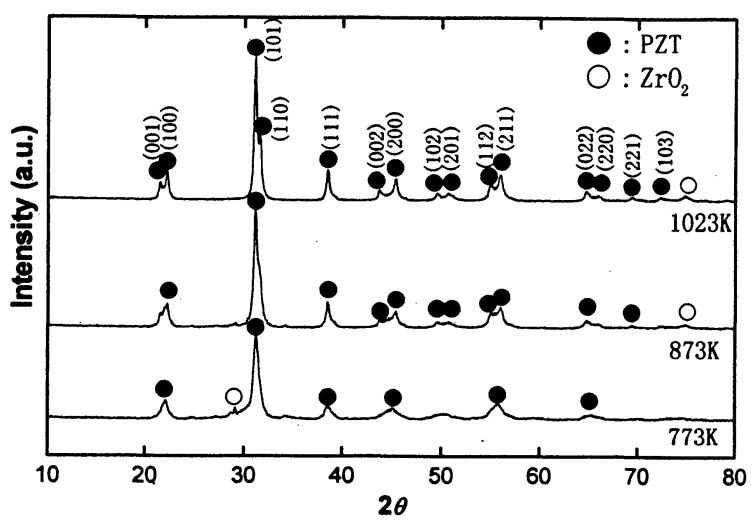

FIG.2. X-ray diffraction pattern of PZT (No.2) powder.

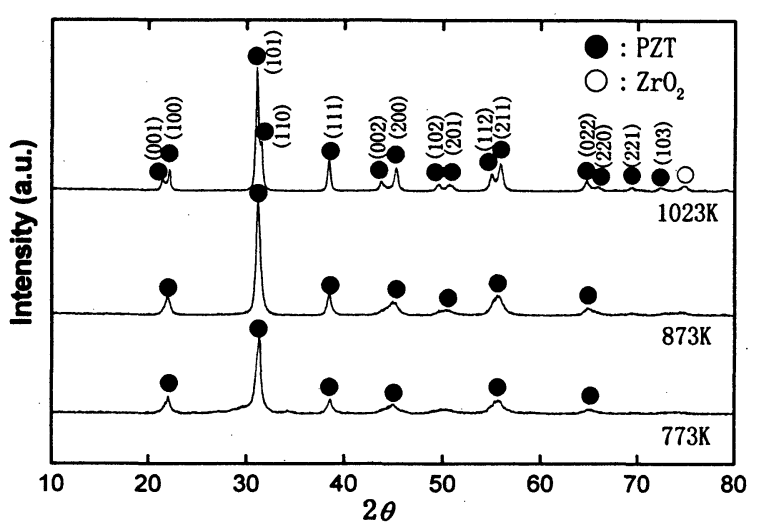

FIG.3. X-ray diffraction pattern of PZT (No.12) powder.

$\mathrm{PZT}$ 粉末の作成において、ゾルーゲル法を用いること の有用性を検討した。 X 線回折パターンから推測する限 り、金属アルコキシドを使う方法も、水溶性金属化合物 を使う方法を用いてもほぼ同じ X 線回折パターンを得ら れることがわかった。しかし、Fig.2 および Fig.3 に示 したX線回折分析の結果、873K 以上で焼結すると結晶 性の高い粉末が生成する、つまり、焼成条件により、結 晶成長に大きな違いが生じることが明らかになった。た だし、焼結温度を $1023 \mathrm{~K}$ まで上昇させると、unknown ピークが認められた。ICDD データより、このピークは 斜方晶系二酸化ジルコニウム $\left(\mathrm{ZrO}_{2}\right)$ であると推測でき た。さらに、焼成温度が $773 \mathrm{~K}$ の際、一部黒い粉体が確 認された。これは、溶媒、もしくは金属アルコキシドの 炭素成分が残存しているものと考えられる。

\section{REFERENCES}

1 H. Sakai and T. Tuchiya, J. Ceram. Soc. Jpn., 99 ( 7 ) 630-634 (1991).

2 T. Hukui, TAIKAZAIRYOU, 143, 52-60 (1996).

Presented at '98 SAS Intelligent Symposium 